\title{
Digital Transformation in South Africa's Short-Term Insurance Sector: Traditional Insurers' Responses to the Internet of Things (IoT) and Insurtech
}

\author{
Andrew J. Moodley \\ Master's Student, LINK Centre, University of the Witwatersrand (Wits), Johannesburg \\ iD https://orcid.org/0000-0001-6390-4806
}

\begin{abstract}
This article explores the impact of the internet of things (IoT) and insurtech on South Africa's short-term insurance industry. The research found, based on interviews with high-level players in or connected to the South African industry, that while IoT and insurtech are significant potential drivers, the country's incumbent insurers have to date been slow to adopt these digital transformation elements in their business models. This article outlines the drivers of IoT and insurtech, the factors influencing the slow adoption of these elements by traditional South African insurers, and recommendations for the adoption of these elements by South African insurers.
\end{abstract}

\section{Keywords}

insurance, insurtech, internet of things (IoT), business models, digital transformation, South Africa

\section{Acknowledgement}

This article draws on the contents of the author's 2018 research report for the Advanced Professional Practice in Digital Innovation and Leadership course, LINK Centre, University of the Witwatersrand (Wits), Johannesburg.

DOI: https://doi.org/10.23962/10539/28657

\section{Recommended citation}

Moodley, A. (2019). Digital transformation in South Africa's short-term insurance sector: Traditional insurers' responses to the internet of things (IoT) and insurtech. The African Journal of Information and Communication (AJIC), 24, 1-16. https://doi.org/10.23962/10539/28657

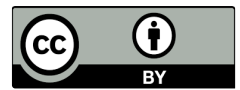

This article is licensed under a Creative Commons Attribution 4.0 International (CC BY 4.0) licence: https://creativecommons.org/licenses/by/4.0 


\section{Introduction}

South African short-term insurers-providers of short-term coverage products, as distinct from annual policies-operate within a highly regulated financial services industry (Short-term Insurance Act 53, 1998; Maupa, 2018). The South African insurance sector, similar to the global industry, is in a continual state of transition, influenced by, inter alia, changing economic factors, privacy laws, customer rights, and access to information requirements (SAIA, 2019). As the needs of consumers evolve and mature, insurers face a continuing challenge to maintain relevance with policyholders (EY, 2017). However, in a digitally transforming sector, traditional insurers have to contend with insurtech start-ups that are using emerging technologies (including internet of things (IoT) technologies), analytics, and other digital transformation capabilities to disrupt traditional insurers' value propositions (IBM, 2011; Pillay, 2019).

South Africa's incumbent short-term insurance players have demonstrated limited adoption of IoT technologies, which can enable new or improved policyholder insights, enable new or improved insurance product and business model innovations, and drive a transformational shift in the value provided to policyholders (EY, 2016; $\mathrm{PwC}$, 2016). By adopting an IoT-centric business model, an insurer can use realtime information to build or improve its products, service models and portfolioas opposed to using traditional mechanisms, which rely on historical, periodically updated, macro-level data (EY, 2017).

Several South African companies have been providing vehicle-tracking telemetry technology, which is essentially an elementary application of IoT technology, to the insurance sector since the 1990s, but these vehicle-tracking companies, and the insurers, have been slow to leverage the telematics data to provide insurtech benefits in their products (Geotab Africa, 2019; Minnie, 2018).

Due to the still-nascent state of insurtech in South Africa, there is very little published information about insurtech offerings in the country, and the sector information for this study was gathered from news articles, organisational webpages and promotional material. Those insurtech firms that seem to be gaining traction in South Africa have a strong focus on using automation, cloud-based systems, machine learning and mobile apps to modernise the insurance experience or capability, with little use of IoT technology (Littlejohns, 2019). The use of IoT in South Africa is emerging, but with a focus on monitoring and measuring, and its application to the insurance sector is limited (Mpala, 2018).

There are examples of digital start-ups that have developed insurance sector solutions in partnership with a traditional insurer, such as a solution for preventing and reporting geyser (tanked water heater) bursts (Santam Specialist Real Estate, 2019). This geyser solution can also provide the homeowner with an app to manage 
the geyser and its environment, to leverage machine-learning-delivered insights on the behaviour of the geyser environment, and to benefit from other potential sensors connected to the IoT device (Jonckie, 2019).

In 2016 it was estimated that 65\% of vehicles and households in South Africa were not insured, presenting a significant opportunity for insurers ( $\mathrm{PwC}$, 2016). Even with that low level of short-term insurance take-up, the sector earned ZAR102 billion in billed premiums in 2018 (KPMG, 2019). Figure 1 shows the leading players, and their revenue sizes, in the short-term insurance industry in South Africa in 2018, based on annualised premiums collected (KPMG, 2019).

Figure 1: South African short-term insurance market in 2018 (annualised premiums, in ZAR billions)

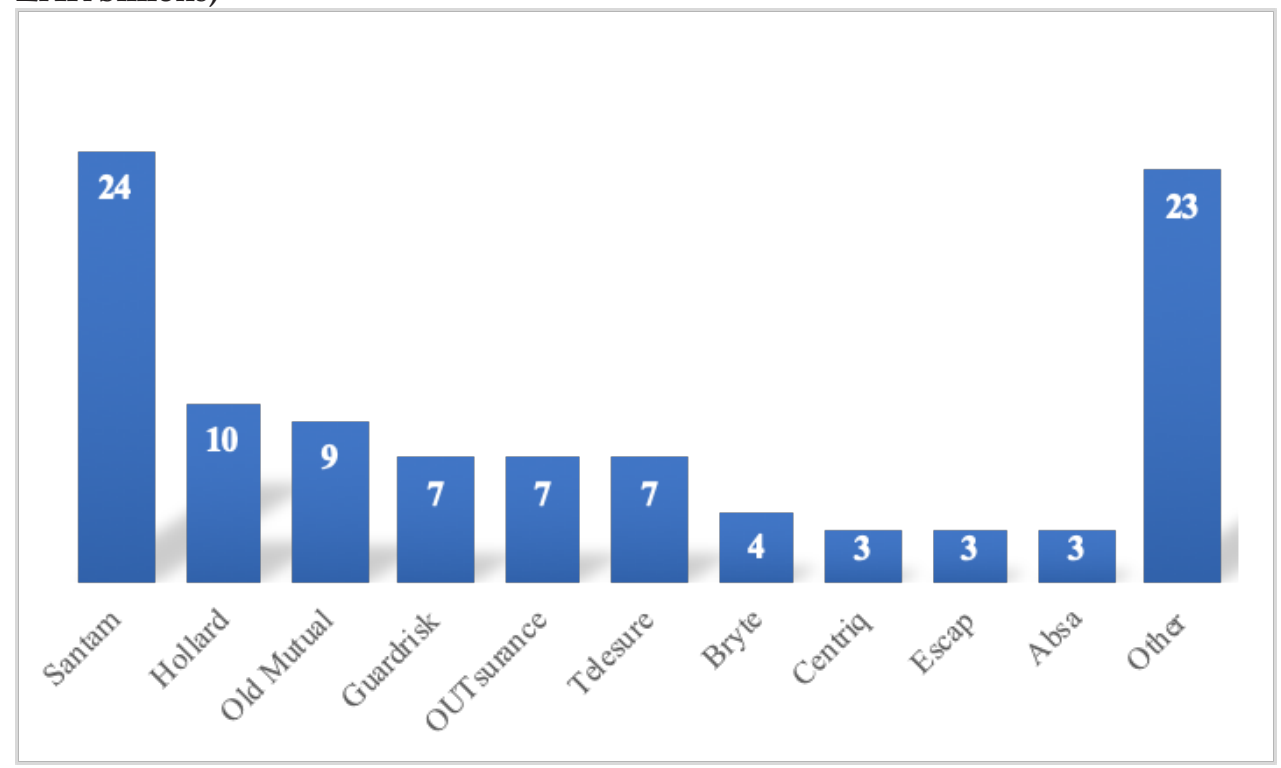

Source: KPMG (2019)

In 2016, according to Accenture (2016), an estimated 55\% of South African policyholders had changed insurers in the preceding three to five years in order to pay reduced premiums. It has also emerged that traditional insurance models are not attractive to South African millennials (people born between 1981 and 1996), who make up 28\% of the market (Tayengwa, 2017). Millennials, who are "digital natives", present a clear challenge to any insurer that has low engagement, and low investment, in digital transformation strategies (see Ayuso, Guillen \& Nielsen, 2019).

Insurtech companies are demonstrating the value of digital innovations in the provision of insurance products. Among other things, these companies use social media platforms to create shared-risk peer groups, i.e., peer-to-peer (P2P) insurance 
options ( $\mathrm{PwC}, 2016)$. The entire peer group benefits, in profit distribution and premium reduction, from risk mitigation and risk reduction mechanisms adopted by the group's members (Sandquist, Gasc \& Sollmann, 2015). The insurer can create and adjust incentives based on the behaviours that influence the reduction of insurance risk factors or claim frequency, which the insurer benefits from directly in both claim reduction and perceived value by the policyholder (Maupa, 2018).

Meanwhile, the traditional short-term insurance business models thrive on the economic principle that the premiums of a large number of non-claiming policyholders sufficiently cover the payouts to the comparatively smaller number of policyholders who claim, with the premium levels modelled to the guaranteed financial advantage of the insurer (Tayengwa, 2017).

Many South African vehicle owners have accepted the installation of third-party telemetry devices for data collection to aid in stolen vehicle recovery (EY, 2016). These devices collect, store and transmit information such as speed, GPS location and engine performance to a central collection point, such as a vehicle tracking company (Ayuso et al., 2019). Vehicle telemetry devices, which use telematics for their operation, have been in the mainstream for many years in South Africa, and have evolved to include driver behaviour-reporting and accident-scenario determination (Accenture, 2016; Ayuso et al., 2019).

There is undoubtedly a need for South Africa's incumbent, traditional short-term insurers to leverage the business benefits offered by the current implementation of digital technology in the sector, and to evaluate their investment choices with cognisance of the insurtech sector's digitally enabled risk calculation, mitigation and policyholder engagement technologies (EY, 2017). Increasing the use of IoTgenerated data in product innovations has the potential to optimise costs, decrease premiums, and allow many of the uninsured to take up insurance tailored to their social, economic and geographic circumstances (Sandquist et al., 2015).

\section{Perspectives from the literature}

\section{The internet of things (IoT)}

The IoT has enabled globally and functionally disparate networks and devices to interact with one another (Lee, 2019; Marek \& Woźniczka, 2017). This interaction is enabled by devices that act as a bridge between geographically or topologically disparate networks and devices. These bridges perform local activities, in response to data from their attached sensors, and communicate this data to an online platform for rapid analysis, optimisation and functional adaption (Kang \& Choo, 2018; Lee, 2019). This phenomenon of devices that can dynamically communicate and respond is positively contributing to the way organisations design their services and how customers can consume them (Porter \& Heppelmann, 2015). 
An intelligent device can be any device or thing, embedded with a combination of sensors, actuators and microprocessors, that is proficient in communicating with other devices, systems or even humans (Kang \& Choo, 2018). With the advent of IoT and real-time, bi-directional communication, machines and things, not only humans, will be regarded as the customers of an organisation (Hung, 2017). Things becoming customers, while these things are simultaneously augmenting customers' experiences, will create an environment where some of the traditional intermediaries between producers and their customers are potentially bypassed (Porter \& Heppelmann, 2015). Io $T$ enables the consumer to digitally interact with products, including maintaining, monitoring, conserving, adjusting and allocating activities (Groopman, 2015). This interaction enables a new level of active engagement, interaction and feedback between consumers and producers (Hung, 2017).

Consumers will embrace and adopt interactive technology as they increasingly gain positive experiences and outcomes from such engagements (Marek \& Woźniczka, 2017). With this increase in interactions, a service provider will organically receive more usage data from its customers. As these data points grow, so does the precision of analytics (Porter \& Heppelmann, 2015). Analytics develop the service provider's ability to understand customer expectations, which in turn inform product innovation and development, user experience, preventative maintenance, and service delivery innovations, shifting them into a data-driven business (Groopman, 2015). Consider that the traditional urban spaces that people occupy are being transformed into digitally enabled smart cities, driven by the expectation that $60 \%$ of the world's population will be urbanised by 2025 (Petrolo et al., 2015). A smart city operates by using technology that leverages sensor data, from IoT-connected devices within the city, to enable citizen services on a large, co-ordinated scale (Hancke, Silva \& Hancke, 2012). The integration of IoT into a city changes risk variables and reduces certain risk factors, while at the same time introducing new risk considerations (Breading, 2017).

\section{IoT's transformation of business models}

Fuster and Scherrer (2015) examine how new ideas, solutions and services can be created from the collecting, analysing and processing of IoT data that smart devices provide on products' utilisation, contents and consumption. IoT-data driven capability enables organisations to develop or improve products as well as build useful services and businesses (Lee, 2019). It encourages the organisation to broaden its value proposition and reshape itself to leverage the new opportunities that smart devices provide (Porter \& Heppelmann, 2015). Business benefits include operational improvement, in-usage optimisation, and preventative maintenance of products-coupled with digitally supported, proactive, and data-driven engagement and response to the market (Hung, 2017). McAfee and Brynjolfsson (2012) show how organisations that leverage data-driven insights to transform their operations or business models perform better on objective financial and operational metrics when compared to their industry counterparts that do not engage in such transformations. 


\section{IoT and South Africa's short-term insurance sector}

Four factors that catalyse innovative disruption are: (1) a new entrant's product or service addresses consumers' current challenges faced with existing suppliers; (2) existing suppliers are replaced by a new entrant providing an innovative, technologyenabled offering; (3) there are no significant regulatory barriers to impede the disruptive innovation or innovators; and (4) there is aggressive investment from investors driving the adoption of a new innovation or technology (KPMG, 2019). South Africa's incumbent short-term insurers need to consider these factors when determining how to remain relevant to the evolving digital needs of policyholders, to a consumption economy, and to a sector shifting to insurtech (Svahn, Mathiassen, Lindgren \& Kane, 2017). The traditional insurer needs to develop the competencies in digital product innovation necessary to satisfy policyholders looking for insurance personalisation, i.e., customisation to their specific social, economic and risk circumstances (IBM, 2011).

Sandquist et al. (2015) describe how insurers adapting to the changes brought by insurtech are focusing on data-driven customer experiences, channel digitisation, the role of ecosystems and IoT. The introduction of IoT-enabled insurance products allows the insurer to introduce experiential value and rewards for the adoption of risk-reducing behaviours. These activities can positively drive the insurer's relevance in the market (Cortis, Debattista, Debono \& Farrell, 2019; EY, 2016). IoT adoption is growing, driven by three distinct technology trends (Porter \& Heppelmann, 2015). The first is the volume of data generated and received using a variety of technologies and communication standards. The second is the maturity of cloud-based technologies, which now enable the affordable collection, storage and conversion of data into meaningful information. The third is the growing presence of always-connected mobile, smarter and more socially collaborative networks that make vast amounts of information available for decision-making and real-time response (Marafie, Lin, Zhai \& Li, 2018). Insurers who integrate these trends into their business models are reaping the rewards. For example, Tayengwa (2017) found that IoT adoption enabled insurers to reduce their quoting and underwriting processing time by as much as $60 \%$, enabling cost reduction and improving policyholder experiences.

Natural disasters affect everyone in a community, and they may result in the loss of property and lives. An IoT-enabled disaster management system can be unified and integrated using real-time alerts and historical data analysis to determine probable areas needing emergency services, crisis management teams and critical relief when a disaster occurs. Insurers can leverage these types of disaster management systems to equip themselves and manage their response in the event of disaster striking (Koduru, Reddy \& Padala, 2018). Another emerging trend is the integration of IoT data with analytics tools to build a holistic picture of a risk environment or to manage claims (EY, 2016). Data collected from connected vehicles, buildings and other insured assets are passed on to analytics systems to influence the insurers' processing 
and underwriting claims (Chekriy \& Mukhin, 2018; Cortis et al., 2019). Analytics enable automated claims payment and assist in fraud detection, thus improving the underwriting process and driving down the cost of transactions (McAfee \& Brynjolfsson, 2012).

\section{IoT, insurance industry regulation and privacy}

The South African Insurance Association (SAIA) is the representative body of the country's short-term insurance industry, and its Executive Committee comprises the country's prominent short-term insurers (SAIA, 2019). Existing insurance industry regulations do not promote digital technologies (SAIA, 2019). The composition of the SAIA Executive Committee may be a limiting factor for the sector, given the potential for the protection of self-interest in regard to the regulation of insurtech.

Globally, consumer rights and information privacy are significant trends in influencing policy and regulation within the insurance sector (Maupa, 2018). Technology innovations have a direct influence on the rise of data privacy and security challenges for insurers and other users of IoT technologies (Zhou, Jia, Peng, Zhang \& Liu, 2019). Policyholders are sometimes not consciously aware of their data passing. through networks and the storage devices of the insurers and their service providers (Porter \& Heppelmann, 2015). This invisible data collection is driving the emerging challenge of digital trust and privacy for the insurance sector (Fuster \& Scherrer, 2015). Data collection allows the insurer to provide services to the policyholder that it could otherwise not provide (Petrolo et al., 2015). It simultaneously places an obligation on the insurers to mitigate the leakage of this data, as such leakage could affect the security or invade the privacy of the policyholder (Fuster \& Scherrer, 2015). In an always-connected world, it is often difficult to quantify how the data generated is used to benefit the policyholder directly and what data generation unnecessarily compromises the policyholder (Zhou et al., 2019).

\section{Research methodology}

This study employed a qualitative data-gathering method, via semi-structured, oneon-one interviews with eight senior executives in, or linked to, the South African insurance sector. These interviews occurred between February and April 2018, at the corporate offices of each of the executives, in Johannesburg. The eight executives interviewed (see Appendix A) were from four entities:

- a short-term insurer;

- an organisation building insurance products for short-term insurers;

- a telecommunications operator involved in providing IoT services to the market; and

- an established leader in IoT technology for the South African short-term insurance sector. 
The interviews generally followed an Interview Guide (see Appendix B), and focused on understanding:

- how IoT can enable or improve market insights for insurance providers;

- what new or improved insurance models or products are possible through the adoption of IoT; and

- how IoT adoption can transform the short-term insurance market.

\section{Findings}

\section{IoT and insurtech in South Africa's short-term insurance sector}

There was a consensus amongst all eight respondents that IoT technology is essential to South Africa's short-term insurance sector, with the current use of IoT being the use of sensors for event reporting (fire, water, smoke, security alarms); telemetry for asset tracking (vehicles, animals and cargo); human activity tracking to measure healthy behaviours (motion and body statistic sensors); and GPS data for locationbased risk calculation.

Five respondents stated that, among the many advantages offered by data-driven insights, they enable policyholders to be voluntarily involved in constant, bi-directional and positive engagement with the insurer. Customer engagement increases, plus the policyholder becomes an active participant and partner in understanding and mitigating risk factors. Cooperation by policyholders releases the insurer from a permanent supervisory and educational cycle with its policyholders regarding risk prevention. The insurer is also able to adjust or modify its rewards systems based on the learnings it derives from the data collection. Policyholders who elect not to meet the adjusted reward conditions do so knowing that this may negatively affect their premiums, benefits or rewards, according to three respondents.

Telemetry use in South Africa originated in the nature conservation sector, leveraged for animal location and anti-poaching activities. South African insurers did not actively seek vehicle-tracking telemetry technology, but instead were introduced to it by technology entrepreneurs. According to two respondents, IoT use in South Africa began approximately two decades ago, when a local organisation partnered with international counterparts to bring industrial telemetry technology to the market. Insurance companies adopted this technology, which proactively transmitted the vehicle's location and movement to aid in stolen vehicle location and recovery. These respondents noted that, around a decade ago, the sector evolved from employing telemetry data for only vehicle location and recovery to also include driver behavioural monitoring and rewards systems. As the technology matured, the traditional insurers leveraged their vehicle telemetry data to evolve their product offerings. They used data analytics to derive new insights into risk factors affecting motor vehicles and engaged policyholders in risk-lowering activities. 
All the respondents observed that conditions in South Africa's short-term insurance sector are ripe for insurtech offerings to emerge. A few years ago, an insurtechcentric organisation would have struggled to find resources, capability and market receptiveness. The success of other risk/reward models in the broader market has created a platform for the establishment of insurtech. Additionally, in South Africa, the socio-political environment is conducive to modalities that can grow insurance take-up by the large numbers of people currently uninsured. Value-based insurtech models are highly relevant to the South African context because of their ability to provide differentiated pricing models based on the effect of environmental or situational conditions on the insured item.

\section{IoT and insurtech's impacts on the insurance sector's business models}

Traditionally, short-term insurers have determined their risk calculation models based on data gathered at the time of policyholder signup or during a claims process. Digital technologies are changing the face of risk calculation. Two respondents working with telemetry indicated that when insurers initially adopted vehicle telemetry, the technology and network costs restricted the devices' design and function to only a few data points, with data delivered only every few minutes. By 2018, however, insurers were able to collect over 100 data points per second, due to the increased sophistication of the technology. This significant volume of data presents an unprecedented level of insight into motor vehicle risk factors. All respondents agreed that insurers could employ these data-driven insights to engage their policyholders positively.

Insurtech companies, e.g., P2P insurers, have a digital-technology-led operating model. They engage with the market on digital platforms; engage in real-time policy engagement, claim management and rewards redemption; and engage in risk-sharing models with their policyholder communities. They are employing IoT smart home technology to remodel the way they estimate household risk and to digitally dispatch emergency or security services during an incident. Five respondents mentioned that insurtech companies employ sensors to switch off geysers, water and electricity when a leak is detected, with their platforms automatically dispatching repair technicians based on their GPS location and current work status. The ability to detect a risk event in real-time, act to mitigate it, utilise data to inform the risk model, then update the technology in the field and perform preventative maintenance on other similar-state environments is the automated business model of digital insurers.

Utilising IoT, insurers can cover event types that were previously uninsurable or excluded from a policy. For a variety of reasons, policyholders are not always able to fully comply with their contracted risk agreement with an insurer. Four respondents recommended that, instead of penalising the policyholder during these instances, insurers could instead implement new risk models whereby real-time, noncontractual, incident-based insurance products could be created, used and discarded, 
as required. A respondent gave the example of covering a non-named driver to use a policyholder's vehicle for an errand. Using IoT and mobile application technology, the time of use, the duration of the trip, the driving behaviour and the route of the errand would all be factors that influence the price for that particular insurance instance. Five respondents stated that when small (traditionally uninsured) events are covered in a tailored way, both the insurer and the policyholder gain from the opportunity of a value-adding, bespoke, incident-based, digitally-enabled insurance offering.

\section{IoT, insurtech, and organisational transformation}

All eight respondents were of the view that insurers who leverage IoT data can take new data-driven services and products to market. Two respondents said that, through the use of digital technology, the insurer could move its business model away from only insuring risk to also insuring prevention-of-loss events. All eight respondents were emphatic that IoT is a game-changer for insurers. There was consensus amongst all respondents that South Africa, in general across many sectors, has been sluggish in the adoption of Io $\mathrm{T}$ and in harnessing the enterprise and employment possibilities it creates. Adoption through external introduction emerged as a central theme in how technology adoption occurs in the South African insurance sector. According to four respondents, the country's insurers are slow to adopt new technology, especially single-use or single-purpose devices. The lack of practical use cases, outside of the vehicle and wildlife tracking telemetry cases, is also a factor that inhibits the adoption of IoT in the insurance sector.

According to six respondents, the sector has to date failed to leverage the successful business case of telemetry to drive acceptance of and investment in new products enabled by IoT. Policyholders with the incumbent firms, five respondents stated, will embrace usage-based and value-based pricing models for insurance as they become familiar with the lifestyle options and experiences that such models provide to them. Four respondents indicated that partnerships with, or acquisitions of, existing insurtech players could be a key mechanism through which traditional insurers could allow new learning to enter their organisations, i.e., allowing for internalisation of the insights and knowledge of an insurtech, including understanding the skills required for employees to participate in the insurtech future.

\section{Traditional insurers' resistance to change}

All respondents indicated that organisational resistance to change is prevalent in most incumbent insurance organisations, attributable to the urge to safeguard existing business models and existing stakeholder interests. There is a delicate balance between the financial rewards offered by technology adoption and the magnitude of change 
required to adapt existing business models. Five respondents stated that insurers' propensity to adopt an innovative technology increased as they grew more familiar with its application, as their organisational models evolved due to the technology, and as the ability of the technology to scale across their policyholder base grew.

\section{Impact of smart cities and smart homes}

The communications infrastructure is in place for IoT-driven smart cities and smart homes to emerge strongly in many parts of South Africa, with all the significant mobile GSM telephony providers providing IoT capability on their networks, and with the presence of dedicated IoT networks provided by local and global players, including Consol and Sigfox. Insurtech can be expected to drive the adoption of smart devices in the household, from utility meters to intelligent lighting and security systems.

Seven respondents indicated that the consumer would adopt such technology if the cost of use is lowered, with tangible rewards for the policyholder, such as cost savings or value-adding services. Most homes with internet connectivity have little else connected to the internet or the network, other than personal entertainment and computing devices. An opportunity exists for traditional insurers to look at using their reach, through the existing short-term insurance policies for homes and their contents, to influence the adoption of smart devices, e.g., IoT security cameras, doorbells, lights and locks for insurtech purposes. The insurer could become an active participant in risk mitigation activities, instead of being only the underwriter of theft or loss and allowing a third-party security company to mitigate potential loss with the policyholder.

\section{Privacy and digital trust}

Digital trust is a crucial component of the digital age. Insurers need policyholder data and information to innovate and produce customer-centric solutions and offerings. According to four respondents, some consumers believe that telemetry collects data that can negatively affect their insurance premiums or cover, a sentiment that could prevent those insurers who adopt digital business models from retaining or attracting digital pessimists. Policyholders will yield their personal information if insurers prove that the data collection is done morally and ethically, to benefit the policyholder, and not to discriminate negatively against them. Insurers have to begin the journey of digital transformation to develop digital-centric business models that tangibly benefit policyholders, rather than using the data to preserve existing business models and to penalise policyholders. This journey is challenging for a traditional insurer, declared seven respondents, as it requires the insurer business model to change dramatically. 


\section{Conclusions}

Due to the emergence of IoT and insurtech, traditional South African short-term insurance players have to contend with, among other things:

- potential policyholders' increasing access to competitive product offerings;

- existing policyholders' requirements for higher service levels; and

- shifting business models.

New insurtech entrants move at the speed of digital and do not have the shackles of preserving an existing business model and revenue stream, or of being held back by limitations created by their past. Their lack of history allows insurtech firms to swiftly adopt new ideas, leverage new technology, and appropriate social-commercial models, such as P2P risk-sharing and pay-per-use, to defy and erode the policyholder base of traditional insurers.

In addition to, and in support of, growing their own internal IoT and insurtech capabilities, the traditional South African short-term insurance players should seek opportunities to partner with, and/or acquire, existing start-up insurtech and IoT companies, so as to build competence and capacity in the delivery of IoT-based products and services.

Among other things, lowering barriers for insurance adoption, via IoT and insurtech, can open up insurance options to low-income market segments not previously able to procure insurance-because traditional models made insurance prohibitively expensive and practically unusable. Using technology to create an ecosystem where more consumers can participate in insurance services, through insurtech $\mathrm{P} 2 \mathrm{P}$ insurance communities and value-based models, will help drive the transformation of the traditional insurer business model. The cornerstone of traditional insurance is that the premiums of the many pay for the claims of the few. IoT-enabled, community-based insurtech offerings will allow incumbent insurers to leverage their market position to utilise technology to benefit all stakeholders, who can collectively reduce risks, claims and costs.

\section{References}

Accenture. (2016). Be digital: A R115,2 billion opportunity for South Africa's short-term insurance industry. Johannesburg. Retrieved from https://www.accenture.com/ t20170707T155858Z w /za-en/ acnmedia/PDF-25/Accenture-Be-DigitalPOV.pdfla =en

Ayuso, M., Guillen, M., \& Nielsen, J. P. (2019). Improving automobile insurance ratemaking using telematics: Incorporating mileage and driver behaviour data. Transportation, 46(3), 735-752. https://doi.org/10.2139/ssrn.2885214

Breading, M. (2017). Smart cities and insurance: Exploring the implications. Strategy Meets Action (SMA). Retrieved from https://cdn2.hubspot.net/hubfs/732222/ SMA-RR-2017-Smart-Cities-and-Insurance-082917-V115-Synerscope. pdf?t $=1505751589866$ 
Chekriy, S., \& Mukhin, Y. (2018). Blockchain platform for insurance-related products. Edinburgh: The Glass Cube Company. Retrieved from https://icosbull.com/ whitepapers/3394/i-chain whitepaper.pdf

Cortis, D., Debattista, J., Debono, J., \& Farrell, M. (2019). InsurTech. In T. Lynn, J. G. Mooney, P. Rosati, \& M. Cummins (Eds.), Disrupting finance: FinTech and strategy in the 21st century (pp. 71-84). Palgrave Pivot.

https://doi.org/10.1007/978-3-030-02330-0 5

Ernst and Young (EY). (2016). The Internet of Things in insurance: Shaping the right strategy, managing the right risks. London. Retrieved from https://www.eycom.ch/en/ Publications/20161109-The-Internet-of-Things-in-insurance/download

EY. (2017). The future belongs to the connected: Achieving the vision of digital insurance. London: Ernst \& Young. Retrieved from https://www.ey.com/Publication/vwLUAssets/ ey-achieving-the-vision-of-digital-insurance/\$FILE/ey-achieving-the-vision-ofdigital-insurance.pdf

Fuster, G. G., \& Scherrer, A. (2015). Big data and smart devices and their impact on privacy. Brussels: European Parliament Directorate General for Internal Policies. Retrieved from https://www.researchgate.net/publication/289538954 Big Data and $\underline{\text { Smart Devices and their Impact on Privacy }}$

Geotab Africa. (2019). Adopting usage-based insurance for SA fleets [Blog post]. Retrieved from https://geotabafrica.com/adopting-usage-based-insurance

Groopman, J. (2015). Customer experience in the Internet of Things: Five ways brands can use sensors to build better customer relationships. San Francisco: Altimeter. Retrieved from http://boletines.prisadigital.com/Customer-Experience-in-theInternet-of-Things-Altimeter-Group.pdf

Hancke, G., Silva, B., \& Hancke, J. G. (2012). The role of advanced sensing in smart cities. Sensors, 13(1), 393-425. https://doi.org/10.3390/s130100393

Hung, M. (Ed.). (2017). Gartner insights on how to lead in a connected world: Leading the IoT. Gartner. Retrieved from https://www.gartner.com/imagesrv/books/iot/iotEbook digital.pdf

IBM. (2011). Digital transformation: Creating new business models where digital meets physical. New York: IBM Global Business Services. Retrieved from https://www.ibm.com/ downloads/cas/B6Y8LY4Z

Jonckie. (2019, September 13). Sensor Networks shakes up insurance sector [Blog post]. Retrieved from https://www.insurancechat.co.za/2019-09/sensor-networks-shakesup-insurance-sector

Kang, B., \& Choo, H. (2018). An experimental study of a reliable IoT gateway. ICT Express, 4(3), 130-133. https://doi.org/10.1016/j.icte.2017.04.002

Koduru, S., Reddy, P., \& Padala, P. (2018). Integrated disaster management and smart insurance using cloud and internet of things. International Journal of Engineering $\mathcal{E}^{\circ}$ Technology, 7(2.6), 241-246. https://doi.org/10.14419/ijet.v7i2.6.10777

KPMG. (2019). The South African insurance industry survey 2019. Johannesburg. Retrieved from $\quad$ https://home.kpmg/content/dam $/ \mathrm{kpmg} / \mathrm{za} / \mathrm{pdf} /$ south-african-insurancesurvey-2019.pdf

Littlejohns, P. (2019, June 26). Six South African insurtech start-ups disrupting the country's insurance market [Blog post]. Retrieved from https://www.nsinsurance.com/ analysis/south-african-insurtech-start-ups 
Lee, I. (2019). The Internet of Things for enterprises: An ecosystem, architecture, and IoT service business model. Internet of Things, 7.

https://doi.org/10.1016/j.iot.2019.100078

Marafie, Z., Lin, K.-J., Zhai, Y., \& Li, J. (2018). Proactive fintech: Using intelligent IoT to deliver positive insurtech feedback. In 2018 IEEE 20th Conference on Business Informatics (CBI), Vienna. https://doi.org/10.1109/CBI.2018.10048

Marek, L., \& Woźniczka, J. (2017). The Internet of Things as a customer experience tool. Jagiellonian Journal of Management, 3(3), 163-176. https://doi.org/10.4467/2450114XJJM.17.011.9562

Maupa, M. (2018). 5 trends shaping the insurance industry in 2018 [Blog post]. Retrieved from https://www.fanews.co.za/article/intermediaries-brokers/7/general/1227/5trends-shaping-the-insurance-industry-in-2018/23601

McAfee, A., \& Brynjolfsson, E. (2012). Big data: The management revolution. Harvard Business Review, October, 3-9. Retrieved from http://tarjomefa.com/wp-content/ uploads/2017/04/6539-English-TarjomeFa-1.pdf

Minnie, L. (2018, July 13). Best car tracking devices [Blog post]. Retrieved from https:// www.autotrader.co.za/cars/news-and-advice/automotive-news/best-car-trackingdevices $/ 2655$

Mpala, D. (2018, March 12). 10 South African start-ups leading innovation in IoT [Blog post]. Retrieved from https://ventureburn.com/2018/03/iot-digital-all-stars

Petrolo, R., Loscrì, V., \& Mitton, N. (2015). Towards a smart city based on cloud of things, a survey on the smart city vision and paradigms. Transactions on Emerging Telecommunications Technologies, 28(1), 1-11. https://doi.org/10.1002/ett.2931

Pillay, T. ( 2019). The influence of insurtech on the existing insurance business model. MBA dissertation, University of Pretoria. Retrieved from http://hdl.handle. net $/ 2263 / 68935$

Porter, M. E., \& Heppelmann, J. E. (2015). How smart, connected products are transforming companies. Harvard Business Review, October. Retrieved from https://hbr. org/2015/10/how-smart-connected-products-are-transforming-companies

PricewaterhouseCoopers. (PwC). (2016). Insurance through challenging times: Insurance industry. Johannesburg. Retrieved from https://www.pwc.co.za/en/assets/pdf/ insurance-industry-analysis-2016pdf.pdf

Republic of South Africa (RSA). (1998) Short-Term Insurance Act, No. 53 of 1998. Retrieved from https:/www.gov.za/sites/default/files/gcis document/201409/a53-98.pdf

Sandquist, E., Gasc, J.-F., \& Sollmann, R. (2015). Reimaging insurance distribution. Accenture Research. Retrieved from https://financialservices.accenture.com/rs/368-

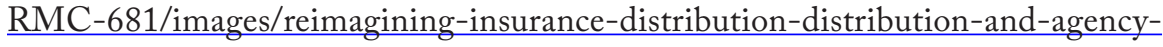
management-survey.pdf

Santam Specialist Real Estate. (2019, May 27). Say hello to the house of the future [Blog post]. Retrieved from https://www.cover.co.za/say-hello-to-the-house-of-thefuture

South African Insurance Association (SAIA). (2019). Board members. Retrieved from https://saia.co.za/board-members.html

Svahn, F., Mathiassen, L., Lindgren, R., \& Kane, G. C. (2017). Mastering the digital innovation challenge. MIT Sloan Management Review, 58(3), 14-16. 
Tayengwa, S. (2017). Digital transformation - the new-age insurer.Johannesburg: TransUnion Africa. Retrieved from https://www.cover.co.za/wp-content/uploads/2017/09/ Digitisation-In-Insurance-Presentation-SamuelT-1.pdf

Vidanagama, T. N. (2017). Towards realization of an IoT environment: A real-life implementation of an IoT environment and its analytics. In 2017 Global Internet of Things Summit (GIoTS), Geneva. https://doi.org/10.1109/GIOTS.2017.8016259 Zhou, W., Jia, Y., Peng, A., Zhang, Y., \& Liu, P. (2019). The effect of IoT new features on security and privacy: New threats, existing solutions, and challenges yet to be solved. IEEE Internet of Things Journal, 6(2), 1606-1616. https://doi.org/10.1109/JIOT.2018.2847733

\section{Appendix A: Interview respondents}

\begin{tabular}{|c|c|}
\hline Respondent & Respondent's expertise and experience \\
\hline $\begin{array}{l}\text { Respondent 1: } \\
\text { Telemetry Expert }\end{array}$ & $\begin{array}{l}\text { C-level Technology Executive in a telemetry company dealing } \\
\text { with all the major insurers. Background in engineering, } \\
\text { business and commercial modelling. }\end{array}$ \\
\hline $\begin{array}{l}\text { Respondent 2: } \\
\text { Telemetry Expert }\end{array}$ & $\begin{array}{l}\text { Technology Executive in a telemetry company dealing with } \\
\text { all the major insurers. Background in engineering, product } \\
\text { development and data modelling. }\end{array}$ \\
\hline $\begin{array}{l}\text { Respondent 3: } \\
\text { Insurance Industry } \\
\text { Executive }\end{array}$ & $\begin{array}{l}\text { Senior Business Executive in a large short-term insurer in } \\
\text { South Africa with an interest in insurtech. Background in } \\
\text { customer services, risk and finance. }\end{array}$ \\
\hline $\begin{array}{l}\text { Respondent 4: } \\
\text { Insurance Industry } \\
\text { Executive }\end{array}$ & $\begin{array}{l}\text { Senior Technology Executive in a large short-term insurer } \\
\text { in South Africa with an interest in insurtech. Background in } \\
\text { technology, procurement and risk. }\end{array}$ \\
\hline $\begin{array}{l}\text { Respondent 5: } \\
\text { IoT Expert }\end{array}$ & $\begin{array}{l}\text { Product Executive in a telecommunications business providing } \\
\text { IoT services to business and consumers. Background in } \\
\text { marketing and product development. }\end{array}$ \\
\hline $\begin{array}{l}\text { Respondent 6: } \\
\text { IoT Expert }\end{array}$ & $\begin{array}{l}\text { C-level Executive in a telecommunications business providing } \\
\text { IoT services to business and consumers. Background in } \\
\text { technology, business and strategy. }\end{array}$ \\
\hline $\begin{array}{l}\text { Respondent 7: } \\
\text { Insurance Product Expert }\end{array}$ & $\begin{array}{l}\text { C-level Executive in a specialised company developing } \\
\text { products and services for insurers. Background in risk, } \\
\text { product development and strategy. }\end{array}$ \\
\hline $\begin{array}{l}\text { Respondent } 8 \\
\text { Insurance Product Expert }\end{array}$ & $\begin{array}{l}\text { Product Executive in a specialised company developing } \\
\text { products and services for insurers. Background in risk, } \\
\text { product development and business. }\end{array}$ \\
\hline
\end{tabular}




\section{Appendix B: Interview guide}

\section{IoT as an Enabler of the Insurtech Sector}

\section{How can IoT enable or improve market insights for insurance providers?}

- Where has IoT been deployed in the insurance sector and to what success?

- How has IoT technology evolved since its inception and what does adoption look like now?

- How did the policyholders and customers react to IoT, or not, in terms of value to them?

2. What new or improved insurance models or products are possible through the adoption of IoT?

- How has IoT affected the relevance of insurance providers' products and services?

- What products and service capabilities are possible because of IoT?

3. How can IoT adoption create a transformational shift in the short-term insurance market?

- How is IoT redefining or transforming (or how will it redefine or transform) the business of insurance?

- How will traditional insurance companies contend with digital-first new next generation IoT companies? 